\title{
Effects of Utah Juniper Removal on Herbage Yields from Springerville Soils ${ }^{1}$
}

\section{WARREN P. CLARY}

\section{Plant Ecologist, Rocky Mountain Forest and Range Experiment Station, 2}

Flagstaff, Arizona.

\section{Highlight}

Yields of understory vegetation increased from $223 \mathrm{lb}$./acre, including $50 \mathrm{lb}$. of perennial grasses, to $981 \mathrm{lb}$., including $193 \mathrm{lb}$. of perennial grasses, after juniper overstory was removed in northern Arizona. Successional trends did not follow a smooth sequence; many areas remained in an annual forb-half-shrub stage for severai years.

Thickening of established pinyon-juniper stands, and invasions of new stands into former grasslands, have reduccd the amount of available forage in central and northern Arizona. The average yields of herbage vary from $620 \mathrm{lb}$./acre with no pinyon-juniper to about $40 \mathrm{lb}$./acre with an $80 \%$ canopy intercept (Arnold, Jameson, and Reid, 1964). This reduction

\footnotetext{
${ }^{1}$ Received September 16, 1970.

${ }^{2}$ Forest Service, U. S. Department of Agriculture, with central headquarters maintained at Fort Collins in cooperation with Colorado State University; author is located at Flagstaff in cooperation with Northern Arizona University.
}

of herbage yield due to overstory is more pronounced on heavy clay soils such as the Springerville series (Jameson and Dodd, 1969). Dense stands of Utah juniper, ${ }^{3}$ the most common juniper in Arizona woodlands, can so dominate a site that the soil surface is nearly barren of understory grasses and forbs.

Interest has been widespread in removing pinyon-juniper overstory to improve the range forage supply and increase overland water yields. The advisability of juniper conversion on Springerville soils has been questioned, however, because of the difficulty in subsequently establishing forage grasses.

In this study we examined (1) the relationships of herbage production on Springerville soils to Utah juniper overstory, and (2) the response of understory plant yields to the cabling of Utah juniper and the seeding of forage species.

Arnold et al. (1964) reported that mechanical juniper control

${ }^{3}$ Common and botanical names of plants mentioned are listed in Table 1 . abruptly released suppressed halfshrubs, mainly broom snakeweed. Mid-grasses increased slowly after juniper control, short-grasses increased at least up through the fifth year, and perennial forbs showed no marked response. Annuals increased during the first two growing seasons after juniper removal, and declined after the fifth season as they were displaced by perennials. Total herbage production reached a peak approximately 10 years after juniper control.

In an Arizona study on limestone soils, perennial grass yields on droughty sites had not increased 4 to 5 years after removal of pinyon-juniper. On sites with higher rainfall, perennial grasses had increased two to four times (O'Rourke and Ogden, 1969).

\section{Study Area and Methods}

The study was made in the Utah juniper subtype of the pinyonjuniper woodland at an elevational range of 5,200 to $5,800 \mathrm{ft}$, on the Beaver Creek Pilot Watershed (Worley, 1965), approximately 40 miles south of Flagstaff.

Precipitation falls in two distinct periods-as rain in July and August, and as snow or rain from December to March. Mean annual precipitation for the period of the study (1959 to 1969) was 18 inches.

The principal soil type is Springerville very stony clay. Basalt stones 
Table 1. Common and botanical names of plants mentioned in text and tables.

\begin{tabular}{|c|c|}
\hline Common names & Botanical names \\
\hline \multicolumn{2}{|l|}{ Perennial Grasses } \\
\hline Dropseed, sand & Sporobolus cryptandrus (Torr.) A. Gray \\
\hline Grama, blue & Bouteloua gracilis (H.B.K.) Lag. \\
\hline Grama, hairy & Bouteloua hirsuta Lag. \\
\hline Grama, side-oats & Bouteloua curtipendula (Michx.) Torr. \\
\hline Lovegrass, Lehmann & Eragrostis lehmanniana Nees \\
\hline Lovegrass, weeping & Eragrostis curvula (Schrad.) Nees \\
\hline Sacaton, alkali & Sporobolus airoides Torr. \\
\hline Wheatgrass & Agropyron spp. \\
\hline Wheatgrass, western & Agropyron smithii $\mathrm{Rydb}$. \\
\hline \multicolumn{2}{|l|}{ Annual Grasses } \\
\hline Brome, red & Bromus rubens $\mathrm{L}$. \\
\hline Sprangletop, red & Leptochloa filiformis (Lam.) Beav. \\
\hline \multicolumn{2}{|l|}{ Forbs and Half-Shrubs } \\
\hline Biscuitroot & $\begin{array}{l}\text { Lomatium nevadense (Wats.) Coult. \& Rose and } \\
\text { L. macdougali Coult. \& Rose }\end{array}$ \\
\hline Bladderpod & Lesquerella spp. \\
\hline Deervetch & Lotus humistratus Greene \\
\hline Globemallow & Sphaeralcea spp. \\
\hline Goldeneye, annual & Viguiera annua (Jones) Blake \\
\hline Goosefoot & Chenopodium spp. \\
\hline Grassnuts, purple head & Dichelostemma pulchellum (Salisb.) Heller \\
\hline Groundcherry & Physalis crassifolia Benth. \\
\hline Lettuce, prickly & Lactuca serriola $\mathrm{L}$. \\
\hline Menodora, rough & Menodora scabra A. Gray \\
\hline Penstemon, toadflax & Penstemon linarioides A. Gray \\
\hline Pigweed & Amaranthus spp. \\
\hline Purslane & Portulaca oleracea L. \\
\hline Snakeweed, broom & Gutierrezia sarothrae (Pursh) Britt. \& Rusby \\
\hline Spurge & Euphorbia spp. \\
\hline Sunflower, common & Helianthus annuus L. \\
\hline Sweetclover & Melilotus spp. \\
\hline Sweetclover, yellow & Melilotus officinalis (L.) Lam. \\
\hline Wildbuckwheat & Eriogonum cognatum Greene \\
\hline
\end{tabular}

Shrubs

Manzanita, pointleaf

Mountainmahogany, true

Oak, shrub live

Saltbush, fourwing

Trees

Juniper, Utah

Pinyon

Juniperus osteosperma (Torr.) Little

Pinus edulis Engelm.

Arctostaphylos pungens H.B.K.

Cercocarpus montanus Raf.

Quercus turbinella Greene

Atriplex canescens (Pursh) Nutt.

and cobblestones cover 30 to $50 \%$ of the surface. A representative profile has a clay texture throughout and a 44-inch depth to bedrock (basalt or cinders). The surface layer (0-3 inches) has a granular or platy structure; the lower layers have a massive structure and are extremely hard when dry. tinguish because these soils have a strong tendency to shrink and swell, with much resultant heaving and internal movement. Dry soils have cracks 0.5 to 2 inches wide and 15 to 20 inches deep. The cracks disappear when the soils are wet (Williams and Anderson, 1967).
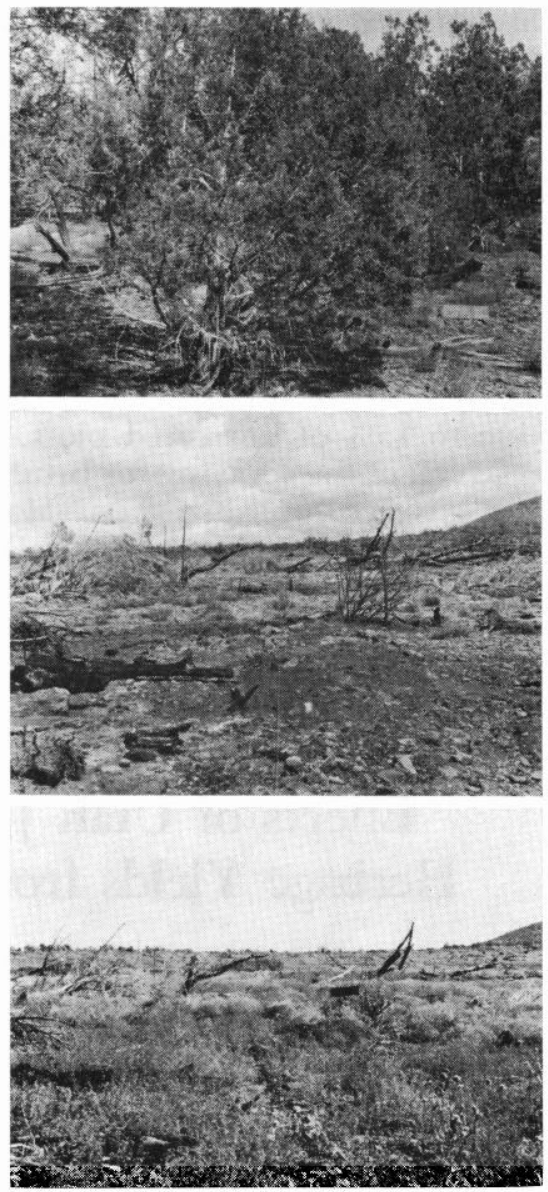

Fig. 1. View from a photo point on the cabled experimental area (upper) before cabling, (middle) 1 year after cabling, and (lower) 6 years after cabling.

The overstory (Fig. 1) consisted of 120 Utah juniper trees per acre averaging 7.4 inches d.b.h. (0-29 inches), and 16 pinyon trees per acre averaging 3.9 inches d.b.h. (017 inches) ${ }^{4}$

A large juniper conversion area of over 4,000 acres, and a group of three small experimental areas of 120 to 360 acres, were utilized in this investigation. Differences in treatment schedules provided additional comparisons of treatment effectiveness in improving herbage yields. Trees on the large area were removed over a 3-year period 195759 , and the area was seeded from
${ }^{4}$ Ffolliott, Peter F. An overstory inventory of the lower pinyon-juniper woodland watersheds on the Beaver Creek watershed evaluation project. Unpublished report on file at the Rocky Mountain Forest and Range Exp. Sta., Flagstaff, Ariz. 11 p. 1965. 
the air in 1961 with a mixture of grasses and sweetclover. Trces on one of the small areas were removed in 1963 , and the area was seeded the same year from the ground by means of cyclone hand seeders. On both areas, large trees were uprooted by a heavy cable pulled by two crawler-tractors. Remaining small trees were hand chopped, and slash was burned. Two of the small experimental areas were maintained as controls.

The seed mixture applied on the large area, in total amounts of 1 to $6 \mathrm{lb}$./acre, included sweetclover and five grasses: side-oats grama, blue grama, weeping lovegrass, sand dropseed, and wheatgrass. The seed mixture, in $\mathrm{lb}$./acre, on the small area included the following forage plants: weeping lovegrass, 3.0; side-oats grama, 1.8 ; western wheatgrass, 0.7; Lehmann lovegrass, 0.6; and yellow sweetclover, 0.6; alkali sacaton, 0.2 ; fourwing saltbush, 0.1 ; and true mountainmahogany, 0.1 (Brown, 1965).

Herbage was sampled on a total of 52 clusters of five systematically distributed 9.6 - $\mathrm{ft}^{2}$ plots-12 clusters on the large area and 10 on the small areas. Pretreatment and posttreatment measurements were made on the small areas, but only posttreatment measurements were made on the large area. An averagc of 31 clusters were measured each year, except for 1967 when no measurements were made. Herbage production by species was determined during September of cach year by the weight estimate method (Pechanec and Pickford, 1937).

Thirty-five clusters, five on the large area and 30 on the small areas, contained two 3-step transects (Parker, 1954) for ground cover and plant frequency measurements. These were read at the time of installation in 1959 to 1960 and again in 1965 on the large area, and in 1964 and 1968 on the small areas.

Precipitation was measured by a standard rain gage located in the approximate center of the study area. Percent crown cover of the overstory was determined from 1: 15,840-scale aerial photographs.

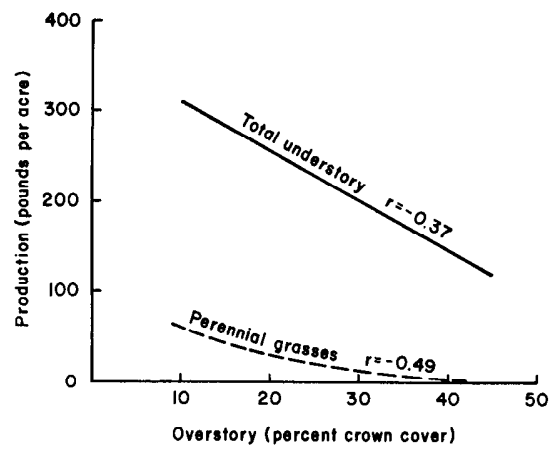

FIG. 2. Relationships of perennial grass and total understory yields to percent crown cover of the intact overstory.

\section{Production of Understory Vegetation}

\section{Overstory Intact}

Yields of understory vegetation (grasses, forbs, half-shrubs, and shrubs) decreased as the overstory of Utah juniper increased. The relationships were significant, but not strong (Fig. 2). The few arcas with a strong perennial grass cover occurred on the upper, rockier portions of the slopes where the trees were smaller and more scattered.

The most productive species under an intact overstory were sideoats grama, broom snakeweed, and shrub live oak (Table 2). Yields of understory vegetation averaged 223 lb./acre annually. The coefficient of variation among clusters was $71 \%$ and among years was $20 \%$.

Annual grass yields were found to be significantly related to JuneAugust precipitation, perennial grass yields to January-August precipitation, and shrub yields to January-May precipitation (Fig. 3). Plants with deeper roots and earlier growth utilized winter moisture, while shallow-rooted late growers utilized principally summer moisture. Forbs and half-shrubs showed little response to changes in precipitation.

Transect measurements on the small undisturbed areas indicated that $35 \%$ of the area was bare soil and litter covered 19\%. Perennial grasses were recorded with $1 \%$ of the Parker loops and combined perennial plants with $12 \%$.
Table 2. Average yields (lb./acre) of understory vegetation on Springcr. ville soils, based on data collected in $1963,1964,1965$, and 1969.

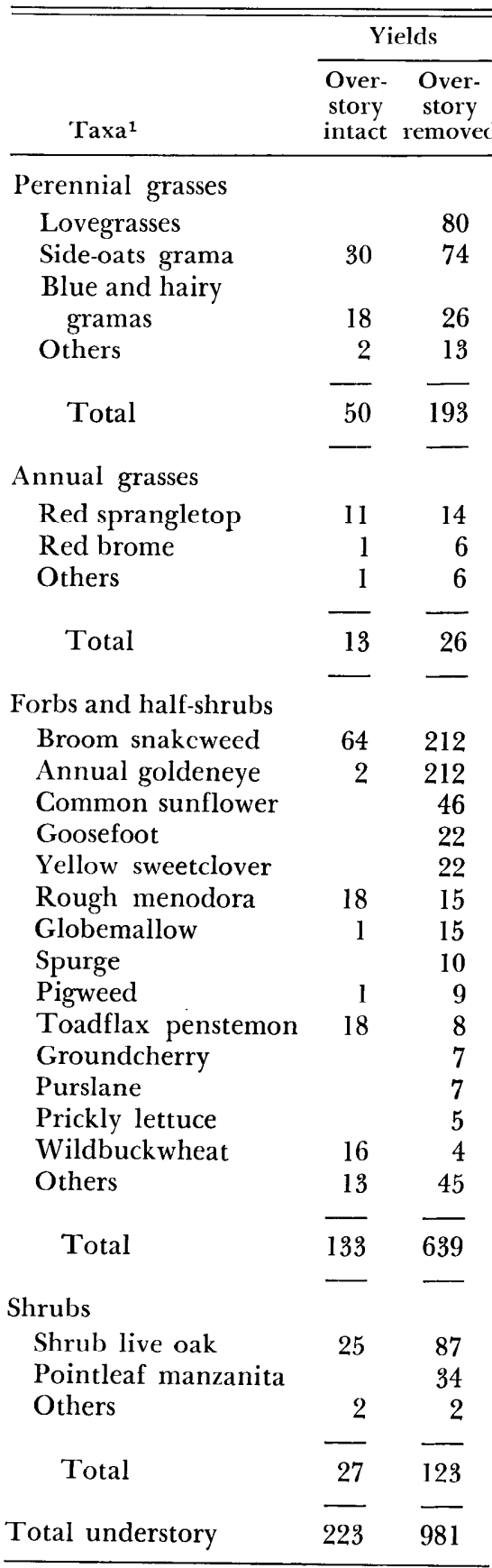

${ }^{1}$ Individual species that contributed $5 \mathrm{lb}$./ acre or more in cither category are listed. Other species such as purple head grassnuts, biscuitroot, bladderpod, and deervetch are oftcn apparent in spring, but disappear before fall measurements.

\section{Overstory Removed}

Yields of perennial grasses after release were not highly predictable. Where seeeding was not successful 


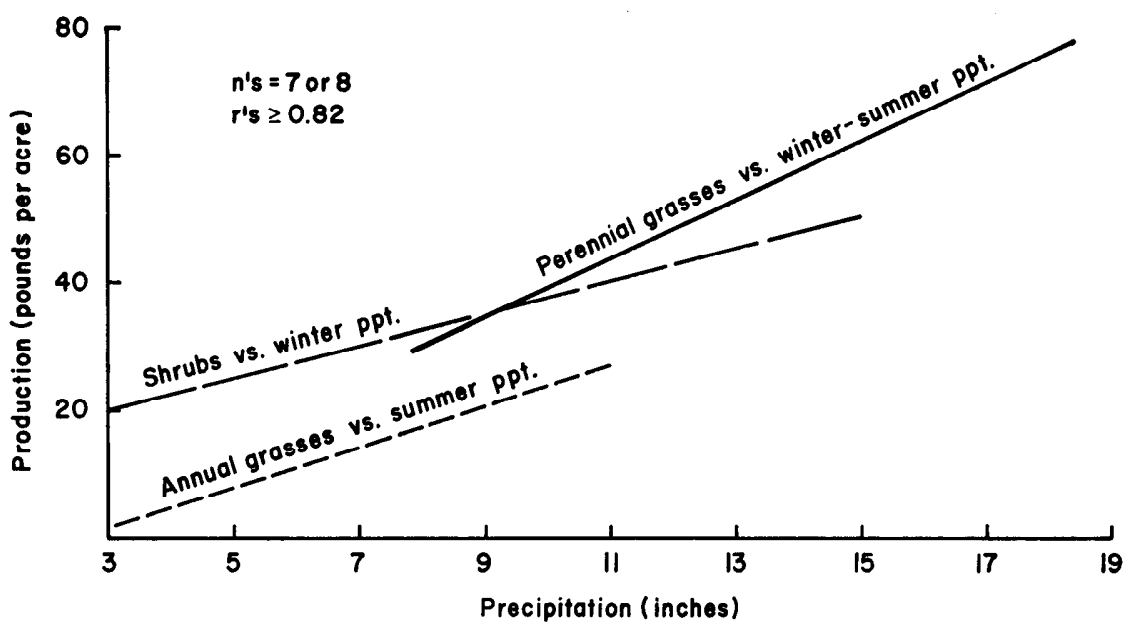

FIG. 3. Relationships of annual grass, perennial grass, and shrub yields on an undisturbed experimental area to precipitation. and native perennial grass remnants were present, yields of perennial grasses were related to time after release and to precipitation. If seeded grasses were successfully established, the yields of perennial grasses increased rapidly the first several years and then fluctuated. Generally, seeding was unsuccessful on the large juniper conversion area and moderately successful on the small experimental area.

Side-oats grama, lovegrasses, broom snakeweed, common sunflower, annual goldeneye, and shrub live oak were the most productive species on the cabled areas. Annual yields of understory vegetation averaged $981 \mathrm{lb}$./acre (Table 2), 758 lb./acre greater than on the intact areas. Roughly one-fifth of this difference in understory yields was in perennial grasses. The coefficient of variation among clusters was $61 \%$ and among years was $41 \%$.

Annual grass and shrub yields did not correlate with differences in precipitation as they did on areas with an intact overstory. Annual goldeneye, an undesirable species which was present in little more than trace amounts under heavy juniper stands, responded strongly to the amount of summer moisture after release (Fig. 4) and became dominant in wet summers. Annual goldeneye has been reported to cause livestock losses when grazed during blooming (Sommerville, 1968).
After 2 years of heavy precipitation (1964 and 1965), the yields of all cabled areas increased relative to undisturbed conditions (Fig. 5). The following year the precipitation was low and the yield of the intact area fell. The yields of the cabled areas with some seeding success were maintained for an additional year, but declined strongly by 1968. This continuation of higher yields into the first dry year is probably a reflection of the upward trend of size and density of new forage plants. In 1969, yields of the native grasses increased, replacing the yields of the exotic lovegrasses which remained low.

Bare soil occupied $36 \%$ of the cabled area, and litter covered $22 \%$. Perennial grasses were recorded with $3 \%$ of the Parker loops, and combined perennial plants with $8 \%$. These readings were little different from the areas where the juniper overstory was intact.

\section{Successional Trends}

Yields of native perennial grasses, most forbs, half-shrubs, and shrubs on the cabled areas tended to increase through time. Yields of the exotic lovegrasses peaked after 4 to 6 years, however, and then declined. Pond (1968) reported a similar pattern. The proportion of lovegrass to total perennial grass decreased from $36 \%$ to $18 \%$ during 1965 to 1969 as native species replaced exotics.

The understory yields did not closely follow the pattern or timetable suggested by Arnold et al. (1964). Ten years after cabling, many clusters were still in the broom snakeweed (a half-shrub) and annual goldeneye (an annual) stage where they began (Table 3). The clusters which initially had little seeded or native perennial grass were still producing no more perennial grass than the average untreated cluster (Table 2). Obviously, the smooth hypothesized successional sequence often does not occur, and many areas will remain in a pioneerlike stage for years after

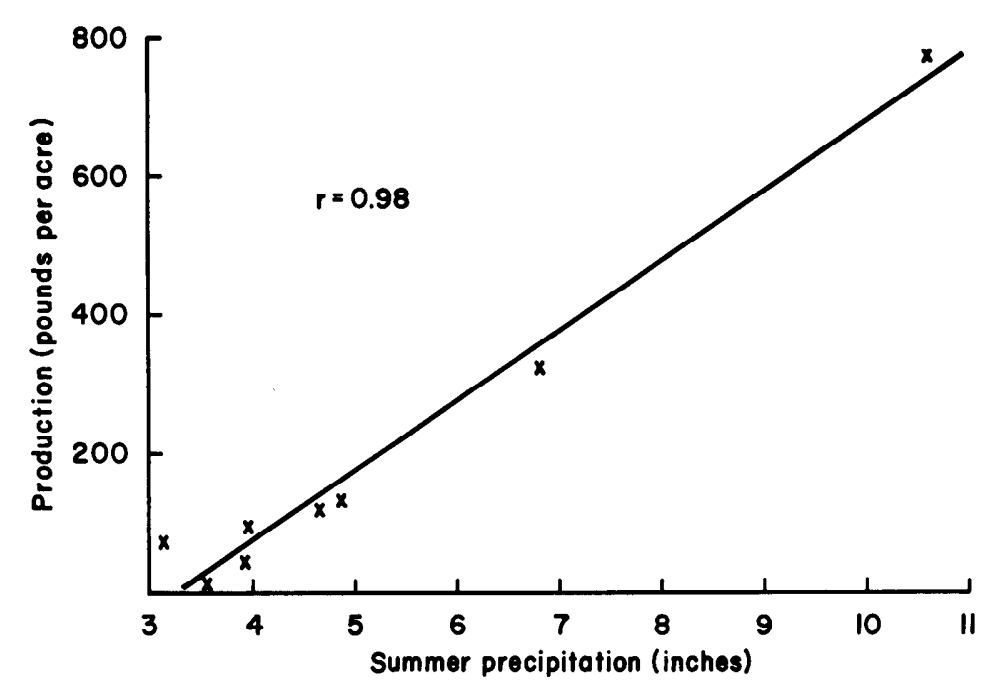

Fig. 4. Relationship of annual goldeneye yields after cabling to summer precipitation. 

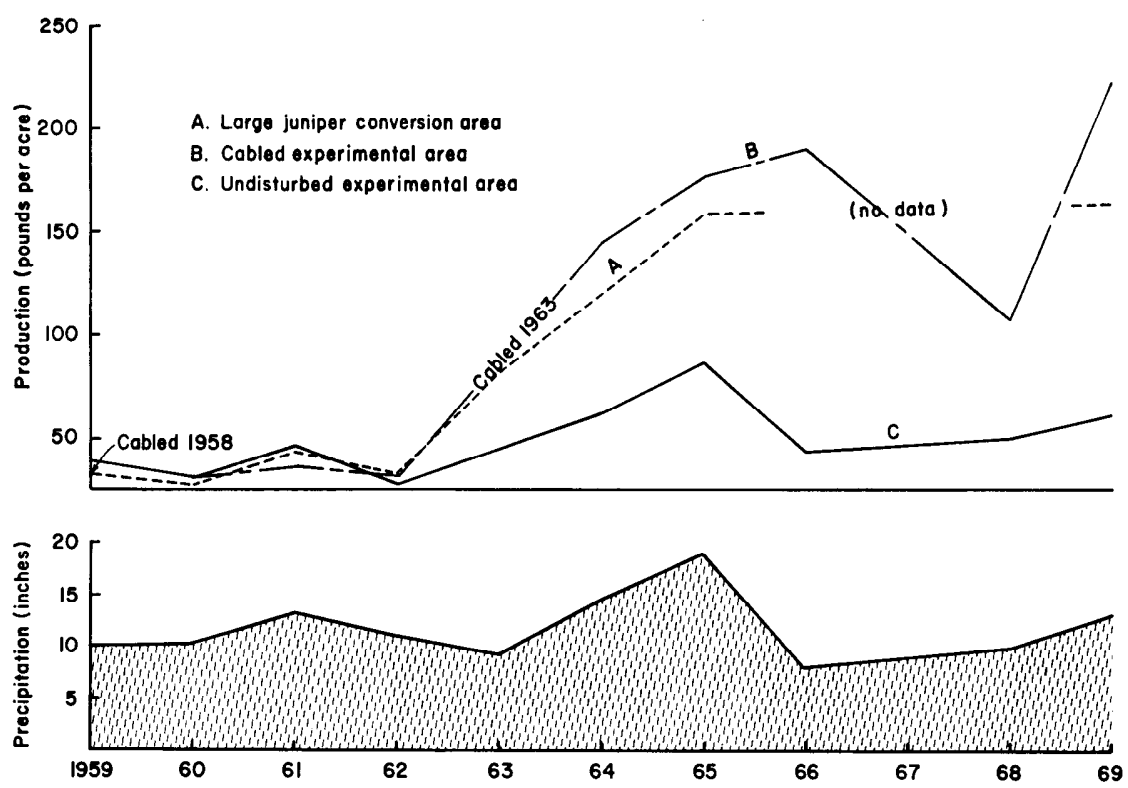

FıG. 5. Relationship of perennial grass yields to cabling and January-August precipitation. (Data from clusters with longest period of record.)

tree removal unless considerable native perennial grass remnants are present, or reseeding attempts are successful.

\section{Summary and Conclusions}

The effect of overstory removal on production of understory vegetation was studied in the Utah juniper subtype of the pinyon-juniper woodland, on Springerville very stony clay soils in north-central Arizona.

1. The yields of understory vegetation with an intact juniper overstory averaged $223 \mathrm{lb}$./acre, including $50 \mathrm{lb}$. of perennial grasses. The yields were negatively correlated with the amount of tree crown cover, but only moderately so. The yields of understory vegetation on areas where the overstory had been removed averaged $981 \mathrm{lb}$./acre, including $193 \mathrm{lb}$. of perennial grass.

2. Where there are few native grass remnants, only very slow improvement in grass yields can be expected on Springerville soils unless the area is reseeded relatively heavily while the soil is still disturbed from the cabling treatment.

3. Under an intact tree overstory, annual grass yields were best related to June-August precipitation, perennial grass yields to JanuaryAugust precipitation, and shrub yields to January-May precipitation. Forbs and half-shrubs under

Table 3. Average 1969 yields (lb./acre) for groups of clusters classified by amount of initial native grass yields and seeding success.

\begin{tabular}{|c|c|c|c|c|c|}
\hline Yields & $\begin{array}{l}\text { Years } \\
\text { since } \\
\text { treatment }\end{array}$ & $\begin{array}{l}\text { Peren- } \\
\text { nial } \\
\text { grasses }\end{array}$ & $\begin{array}{l}\text { Annual Forbs and } \\
\text { grasses half-shrubs }\end{array}$ & Shrubs & Total \\
\hline
\end{tabular}

Initial native grass and first-year seeded grass $<10 \mathrm{lb}$. /acre 10 49 11 1,118 213 1,391

Initial native grass $>10 \mathrm{lb}$./acre and first-year seeded grass $<10 \mathrm{lb}$./acre

First-year seeded a tree overstory showed little response to differences in precipitation. Conversely, where the overstory had been removed, a forb-annual goldeneye-was the only plant responding significantly to differences in precipitation. Its yields were highly correlated with summer precipitation.

4. Successional trends did not follow the typical pattern suggested by Arnold et al. (1964). Many areas remained dominated by an annual forb-half-shrub stage for a number of years after tree removal.

5. Amounts of bare soil were similar between cabled and undisturbed areas.

\section{Literature Cited}

Arnold, Joseph F., Donald A. JameSON, AND ELBERT H. REID. 1964. The pinyon-juniper type of Arizona: Effects of grazing, fire, and tree control. U. S. Dep. Agr., Prod. Res. Rep. 84, 28 p.

Brown, Harry E. 1965. Preliminary results of cabling Utah juniper, Beaver Creek Watershed Evaluation Project. Annu. Ariz. Watershed Symp. Proc. 9:16-21.

Jameson, Donald A., And J. D. Dodd. 1969. Herbage production differs with soil in the pinyon-juniper type of Arizona. U. S. D. A. Forest Serv. Res. Note RM-131, 4 p. Rocky Mountain Forest and Range Exp. Sta., Fort Collins, Colo.

O'Rourke, J. T., ANd P. R. Ogden. 1969. Vegetative response following pinyon-juniper control in Arizona. J. Range Manage. 22:416-418.

Parker, Kenneth W. 1954. A method for measuring trend in range condition on national forest ranges with supplemental instructions for measurement and observation of vigor, composition, and browse. U. S. Forest Serv., Washington, D. C., 37 p.

Pechanec, Joseph F., And G. D. PickFORD. 1937. A weight estimate method for determination of range or pasture production. Amer. Soc. Agron. J. 29:894-904.

Pond, Floyd W. 1968. Changes in grass production on ungrazed converted chaparral. U. S. Forest Serv. Res. Note RM-98, 4 p. Rocky Mountain Forest and Range Exp. Sta., Fort Collins, Colo.

Sommerville, David J. 1968. Goldeneye blamed for cattle losses on south- 
eastern Cochise County ranches.

Ariz. Farmer-Ranchman 47(23):36.

Williams, John A., and Truman C.

Anderson, JR. 1967. Soil survey of Bcaver Creck area, Arizona. U. S.
Dep. Agr., Forest Serv. and Soil Conserv. Serv., in cooperation with Ariz. Agr. Exp. Sta., 75 p.

Worley, David P. 1965. The Beaver Creek pilot watershed for evaluating multiple use effects of watershed treatments. U. S. Forest Serv. Res. Pap. RM-13, 12 p. Rocky Mountain Forest and Range Exp. Sta., Fort Collins, Colo. 